\title{
Impairment of Lamin A/C-Polycomb crosstalk as a possible epigenetic cause of Emery Dreifuss Muscular Dystrophy (EDMD)
}

\author{
Chiara Lanzuolo
}

\begin{abstract}
From 1st French-Italian meeting on laminopathies and other nuclear envelope-related diseases Marseille, France. 15-16 January 2015
\end{abstract}

Traditionally, studies on EDMD have focused on genetic changes affecting molecules involved in the development of pathology. However, emerging findings indicate that a single genetic mutation can be accompanied by a range of different phenotypes, suggesting a contribution of the epigenetic background to the disease progression. This is in line with recent works showing that changes in chromatin architecture are peculiar of several laminopathies [1,2]. Despite much effort has been done to understand the regulation of the complex networks of gene expression that govern muscle differentiation and that is affected in EDMD, little is known about the epigenetic players and molecular mechanisms involved in pathogenesis and progression. Key epigenetic regulators of chromatin architecture are Polycomb group (PcG) of proteins, epigenetic transcriptional repressors of genes primarily involved in differentiation and development [3]. In particular, during myogenesis, modulation of Ezh2 levels, the catalytic subunit of the Polycomb Repressive Complex 2 (PRC2) ensures the correct muscle differentiation [4]. In the nucleus, PcG proteins form microscopically visible foci and high-through-put data together with microscopy analysis revealed that their targets are organized in chromatin loops $[5,6]$. We have shown that Lamin A/C sustains PcG foci influencing PcG nuclear compartmentalization and modulating their repressive functions. During myogenesis, Lamin A/C depletion leads to an altered timing of muscle differentiation due to the aberrant expression of PcG-regulated genes.
Published: 11 November 2015

\section{References}

1. McCord RP, Nazario-Toole A, Zhang H, Chines PS, Zhan Y, Erdos MR, et al: Correlated alterations in genome organization, histone methylation, and DNA-lamin A/C interactions in Hutchinson-Gilford progeria syndrome. Genome research 2013, 23(2):260-9.

2. Shumaker DK, Dechat T, Kohlmaier A, Adam SA, Bozovsky MR, Erdos MR, et al: Mutant nuclear lamin A leads to progressive alterations of epigenetic control in premature aging. Proceedings of the National Academy of Sciences of the United States of America 2006, 103(23):8703-8.

3. Lanzuolo C, Orlando $\mathrm{V}$ : Memories from the polycomb group proteins. Annual review of genetics 2012, 46:561-89.

4. Caretti G, Di Padova M, Micales B, Lyons GE, Sartorelli V: The Polycomb Ezh2 methyltransferase regulates muscle gene expression and skeletal muscle differentiation. Genes \& development 2004, 18(21):2627-38.

5. Bantignies F, Roure V, Comet I, Leblanc B, Schuettengruber B, Bonnet J, et al: Polycomb-dependent regulatory contacts between distant $\mathrm{Hox}$ loci in Drosophila. Cell 2011, 144(2):214-26.

6. Lanzuolo C, Roure V, Dekker J, Bantignies F, Orlando V: Polycomb response elements mediate the formation of chromosome higher-order structures in the bithorax complex. Nature cell biology 2007, 9(10):1167-74.

doi:10.1186/1750-1172-10-S2-O10

Cite this article as: Lanzuolo: Impairment of Lamin A/C-Polycomb crosstalk as a possible epigenetic cause of Emery Dreifuss Muscular Dystrophy (EDMD). Orphanet Journal of Rare Diseases 2015 10(Suppl 2): 010.

Submit your next manuscript to BioMed Central and take full advantage of:

- Convenient online submission

- Thorough peer review

- No space constraints or color figure charges

- Immediate publication on acceptance

- Inclusion in PubMed, CAS, Scopus and Google Scholar

- Research which is freely available for redistribution 